\title{
АНТИОКСИДАНТНЫЙ ЭФФЕКТ ЭРИТРОПОЭТИНА
}

\author{
Лыков А.П., ${ }^{1,2}$ Суровцева М.А., ${ }^{1,2}$, Повещенко О.В. ${ }^{1,2}$, Бондаренко Н.А. ${ }^{1,2}$, Ким И.И. ${ }^{1,2}$, \\ Янкайте Е.B. ${ }^{1}$
}

${ }^{1}$ НИИКЭЛ-филиал ИЦиГ СО РАН, Новосибирск, е-mail: aplykov2@mail.ru; ${ }^{2}$ НМИЦ им. ак. Е.Н. Мешалкина, Новосибирск

Костномозговые мезенхимные стволовые клетки рассматриваются как перспективные клетки для тканевой инженерии. Мезенхимные стволовые клетки мигрируют в поврежденные ткани и органы, внедряются в них и дифференцируются в различные типы клеток, секретируют цитокины и ростовые факторы, участвуют в восстановлении/регенерации тканей. Мезенхимные стволовые клетки получены из аспирата костного мозга больных ИБС, размножены до 4 пассажа и использованы в эксперименте. Оксидативный стресс индуцирован перекисью водорода $(2$ мМ). Антиоксидантный эффект эритропоэтина (Рекормон, 33,4 МЕ/мл) оценивали после предварительного кондиционирования мезенхимных стволовых клеток с эритропоэтином в течение 24 часов и после индукции окислительного стресса по параметрам пролиферации (МТТ-тест), апоптоза и клеточному циклу, экспрессии рецепторов к эритропоэтину. Показано, что прекондиционирование мезенхимных стволовых клеток с эритропоэтином способствует увеличению количества клеток, несущих рецептор к эритропоэтину. Кроме этого, эритропоэтин снижает неблагоприятное действие перекиси водорода на пролиферативный потенциал мезенхимных стволовых клеток. Прекондиционирование мезенхимных стволовых клеток с эритропоэтином уменьшает долю клеток, находящихся на стадии раннего апоптоза и некроза. Таким образом, эритропоэтин проявляет антиоксидантный эффект на мезенхимные стволовые клетки и может быть использован с целью улучшения приживления имплантированных клеток в поврежденные ткани, например при инфаркте миокарда, критической ишемии конечностей.

Ключевые слова: эритропоэтин, костномозговые мезенхимные стволовые клетки, окислительный стресс, пролиферация, апоптоз, клеточный цикл.

\section{ANTI-OXIDANT EFFECT OF ERYTHROPOIETIN}

\author{
Lykov A.P. ${ }^{1,2}$, Surovtseva M.A. ${ }^{1,2}$, Poveshchenko O.V. ${ }^{1,2}$, Bondarenko N.A. ${ }^{1,2}$, Kim I.I. ${ }^{1,2}$, \\ Yankayte E.V. ${ }^{1}$ \\ ${ }^{1}$ Research Institute of Clinical and Experimental Lymphology-Branch of the Institute of Cytology and Genetics SD RAS, \\ Novosibirsk, e-mail: aplykov2@mail.ru; \\ ${ }^{2}$ Institute of Circulation Pathology, Novosibirsk
}

Bone marrow mesenchymal stem cells are considered as promising cells for tissue engineering. Mesenchymal stem cells migrate to damaged tissues and organs, are introduced into them and differentiated into different types of cells, secrete cytokines and growth factors, participate in tissue repair/regeneration. Mesenchymal stem cells were obtained from bone marrow aspirate in patients with ischemic heart disease, multiplied to 4 passages and used in the experiment. Oxidative stress was induced by hydrogen peroxide ( $2 \mathrm{mM})$. Antioxidant effect of erythropoietin (Recormon, 33.4 IU/mL) was evaluated after pre-conditioning of mesenchymal stem cells with erythropoietin for $\mathbf{2 4}$ hours or after induction of oxidative stress according to the parameters of proliferation (MTT test), apoptosis and cell cycle, expression of erythropoietin receptors. It is shown that the preconditioning of mesenchymal stem cells with erythropoietin increases the number of cells carrying the receptor to erythropoietin. In addition, erythropoietin reduces the adverse effect of hydrogen peroxide on the proliferative potential of mesenchymal stem cells. Preconditioning of mesenchymal stem cells with erythropoietin reduces the proportion of cells at the stage of early apoptosis and necrosis. Thus, erythropoietin exhibits antioxidant effect on mesenchymal stem cells and can be used to improve the engraftment of implanted cells in damaged tissues, such as myocardial infarction, critical limb ischemia.

Keywords: erythropoietin, bone marrow mesenchymal stem cells, oxidative stress, proliferation, apoptosis, cell cycle.

Стволовые/прогениторные клетки, в том числе и мезенхимные стволовые клетки (MСК), разновидность мультипотентных стволовых клеток имаго, находят применение в 
тканей [1-3]. Показано, что МСК мобилизуются из костного мозга в периферическое кровеносное русло и мигрируют в другие органы и ткани в ответ на повреждение, например ожог, разрыв мышечной ткани, гипоксию и воспаление. МСК продуцируют широкий спектр биологически активных веществ, включая цитокины, ростовые факторы, хемокины и мессенджеры межклеточного взаимодействия, например оксид азота, что может быть использовано для регенеративной медицины [1-3]. Часто в основе дегенеративновоспалительных заболеваний лежит окислительный стресс [4]. Терапевтический потенциал клеточной терапии стволовыми/прогениторными клетками связан с фенотипом, пролиферацией, миграцией и секрецией биологически активных веществ, в том числе и цитокинов, а также с выживаемостью имплантированных клеток в поврежденный орган или ткань в условии неблагоприятного микроокружения для стволовых/прогениторных клеток [5; 6]. Так, недостаток кислорода и воспаление в зоне патологического процесса могут вызывать гибель вводимых стволовых/прогениторных клеток и снижать их функциональную активность [4]. Показано, что эритропоэтин повышает выживание клеток при гипоксии [7]. Кроме этого, известно, что эритропоэтин способствует эндотелиальной дифференцировке, увеличению экспрессии факторов дифференцировки стволовых клеток, увеличению продукции проангиогенных факторов [5; 6], уменьшению апоптоза [8]. Кратковременная преинкубация стволовых клеток с эритропоэтином увеличивает пролиферацию, миграцию, формирование сосудисто-подобных структур in vitro [9]. Однако эффект эритропоэтина на морфофункциональные свойства мезенхимных стволовых клеток изучен недостаточно.

Цель исследования - оценить эффект эритропоэтина на пролиферацию, апоптоз, клеточный цикл и экспрессию рецептора к эритропоэтину мезенхимными стволовыми клетками при оксидативном стрессе.

Материал и методы исследования. Исследование проведено на костномозговых МСК больных с ишемической болезнью сердца с функциональным классом сердечной недостаточности по NYHA II-III класса, давших информированное согласие. Аспират костного мозга забирали из подвздошной кости традиционным способом под местной анестезией. Мононуклеарные клетки выделяли из костного мозга на градиенте плотности фиколл/верографин $(\rho=1,077$ г/л). Для получения МСК мононуклеарные клетки культивировали в пластиковых флаконах (TPP, Швейцария) в среде DMEM, дополненной 80 мкг/мл гентамицина сульфата, 2 мM L-глютамина и $10 \%$ FCS при $37{ }^{\circ} \mathrm{C}$ в атмосфере $5 \% \mathrm{CO}_{2}$. Через 48 часов неприкрепленные к пластику клетки удаляли, а прилипающую фракцию клеток культивировали до получения конфлюэнтного монослоя (80-90\%). Снятие КМ-МСК при пассировании осуществляли с использованием $0,25 \%$ раствора трипсина $/ 0,02 \%$ раствора ЭДТА. В экспериментах использовали МСК от 4 пассажа. Фенотип МСК до и после 
экспозиции с эритропоэтином исследовали на проточном цитофлуориметре FACSCanto II (BD, США) с использованием моноклональных антител, меченных FITC, РЕ или АРС к CD73, CD90, CD105, CD34 и CD45 (BD, США), рецептору эритропоэтина (BioLegend, CША). Экспозицию МСК с эритропоэтином (Рекормон, Швейцария, в дозе 33,4 MЕ/мл) проводили в течение 24 часов, после этого клетки снимали с использованием $0,25 \%$ раствора трипсина $/ 0,02 \%$ раствора ЭДТА, отмывали в забуференном физиологическом растворе и использовали для оценки фенотипа, экспрессии рецептора к эритропоэтину, пролиферации, апоптоза, клеточного цикла. Клеточный цикл МСК исследовали с использованием пропидиума иодида (BD, США) и апоптоз с использованием Annexin V-FITC Apoptosis Detection Kit (BD, США). При анализе нахождения МСК в фазе клеточного цикла выделяли следующие фазы: subG0G1 (клетки с гиподиплоидным набором хромосом, <2n); G0G1 (клетки с диплоидным набором хромосом, фаза покоя/начального роста, 2n); G2/M (клетки с гиперплоидным набором хромосом, фаза подготовки к митозу/митоз, 2n-4n); S (клетки с гиперплоидным набором хромосом, фаза синтеза/репликации ДНК клеточного ядра, $>4 \mathrm{n}$ ). При анализе нахождения МСК в апоптозе выделяли следующие гейты: некроз (мертвые клетки, окрашенные красителем для нуклеиновых кислот йодистым пропидием), ранний апоптоз (клетки, имеющие нарушение «фосфолипидной асимметрии» мембраны и появление фосфатидилсерина на наружном слое мембраны, выявляемого взаимодействием с антикоагулянтом Аннексином V), апоптоз (клетки позитивные на фосфатидилсерин и нуклеиновые кислоты). Окислительный стресс индуцировали внесением к МСК 2 мМ перекиси водорода, экспозицией в течение 60 минут, отмывкой клеток от перекиси водорода, с последующим использованием МСК для оценки пролиферации, апоптоза и экспрессии рецептора к эритропоэтину. Спонтанную пролиферацию $2 \times 10^{5} \mathrm{MCK/лунку} \mathrm{в} \mathrm{питательной}$ среде ДМЕМ («Биолот», Россия) с добавлением 10\% FCS (фетальной сыворотки плода, Hyclone, CШA), 2мM L-глутамина (ICN, CША) и 80 мкг/мл гентамицина («Дальхимфарм», Россия) исследовали по включению 3-(4,5-диметилтиазол-2-ил)-2,5-дифенил-2Н-тетразолиум бромида (МТT, Sigma, США) на спектрофотометре Stat Fax 2100 (США). 2х105 МСК/лунку, подвергшихся предварительному воздействию окислительного-стресса, культивировали в питательной среде ДМЕМ с добавлением 10\% FCS, 2мM L-глутамина, 80 мкг/мл гентамицина и эритропоэтина (0 и 33,4 МЕ/мл «Рекормон», Швейцария) исследовали по включению 3-(4,5-диметилтиазол-2-ил)-2,5-дифенил-2Н-тетразолиум бромида. Кроме этого, оценивали пролиферацию $2 \times 10^{5}$ МСК/лунку, предварительно проинкубированных с эритропоэтином в течение 24 часов, отмытых от эритропоэтина и далее росших в питательной среде с добавлением 2 мМ перекиси водорода. Статистическую обработку данных проводили с использованием программы Statistica 6.0 for Windows (Stat Soft, США). 
Полученные данные проверяли на нормальность распределения согласно W-критерию Шапиро-Уилкса, меры центральной тенденции и рассеяния описаны медианой (Мe), нижним (Lq) и верхним (Uq) квартилями; достоверность различий рассчитывалась по U-критерию Манна-Уитни и принималась при значениях $\mathrm{p}<0,05$.

Результаты исследования и их обсуждение. Фенотипически клетки, выделенные из костного мозга больных ИБС, соответствовали критериям, предъявляемым для мезенхимных стволовых клеток: экспрессировали CD90, CD73, CD105 и не несли на своей мембране маркер гемопоэтических стволовых клеток CD34 и CD45.

Известно, что функциональная активность МСК зависит от условий микроокружения, в частности от гипоксии [4]. При индукции окислительного стресса перекисью водорода отмечено значимое снижение пролиферативного потенциала МСК по сравнению с контролем ( $<0,05$; табл. 1). Культивирование МСК, предварительно подвергшихся влиянию перекиси водорода, в присутствие эритропоэтина не оказывало значимого влияния на пролиферативный потенциал МСК (p>0,05).

В то же время для МСК, предварительно подвергшихся влиянию эритропоэтина в течение 24 часов, наличие перекиси водорода в питательной среде не вело к снижению пролиферативного потенциала МСК, который был значимо выше по сравнению с пролиферацией МСК после индукции окислительного стресса с последующим ростом в питательной среде с наличием или отсутствием эритропоэтина $(\mathrm{p}<0,05)$.

Однако наличие перекиси водорода в питательной среде с МСК, предварительно подвергшихся влиянию эритропоэтина в течение 24 часов, вело к существенному снижению уровня пролиферации клеток по сравнению с аналогичным параметром для клеток, росших в присутствии эритропоэтина $(\mathrm{p}<0,05)$.

Показано, что окислительный стресс увеличивал апоптоз МСК по сравнению с контролем $(\mathrm{p}<0,05)$. Кроме этого, при окислительном стрессе увеличена доля некротических МСК по сравнению с контролем $(p<0,05)$. Наличие в питательной среде для МСК эритропоэтина также способствовало росту апоптоза и некроза по сравнению с контролем $(\mathrm{p}<0,05)$, но уровень апоптоза/некроза значимо меньше, чем после индукции окислительного стресса.

Предобработка МСК эритропоэтином с последующим культивированием в питательной среде с добавлением перекиси водорода или же наличие эритропоэтина в питательной среде для МСК, подвергшихся предварительно влиянию окислительного стресса, не отменяло увеличение апоптоза и некроза МСК по сравнению с аналогичными показателями МСК после индукции окислительного стресса. 
Эффект эритропоэтина на пролиферацию и апоптоз/некроз костномозговых мезенхимных стволовых клеток в норме и при индукции окислительного стресса

\begin{tabular}{|c|c|c|c|c|c|}
\hline \multirow{2}{*}{$\begin{array}{c}\text { Исследуемый } \\
\text { параметр }\end{array}$} & \multicolumn{5}{|c|}{ Функциональный потенциал мезенхимных стволовых клеток } \\
\hline & $\begin{array}{c}\text { Контрол } \\
\text { ь }\end{array}$ & $\begin{array}{c}\text { Эритропоэти } \\
\text { н }\end{array}$ & $\begin{array}{c}\text { После } \\
\text { индукции } \\
\text { окислительног } \\
\text { о стресса }\end{array}$ & $\begin{array}{c}\text { После } \\
\text { индукции } \\
\text { окислительног } \\
\text { о стресса + } \\
\text { эритропоэтин }\end{array}$ & $\begin{array}{c}\text { После } \\
\text { инкубации с } \\
\text { эритропоэтино } \\
\text { м + перекись } \\
\text { водорода }\end{array}$ \\
\hline $\begin{array}{c}\text { Пролифераци } \\
\text { я }\end{array}$ & $\begin{array}{c}0,88 \\
(0,77- \\
1,03)\end{array}$ & $\begin{array}{c}0,92(0,75- \\
1,06) * \#\end{array}$ & $\begin{array}{c}0,47(0,42-0,74) \\
*\end{array}$ & $\begin{array}{c}0,49(0,42-0,73) \\
* \$\end{array}$ & $\begin{array}{c}0,81(0,48-0,95) \\
\# \$^{\wedge}\end{array}$ \\
\hline \multicolumn{6}{|c|}{ Апоптоз/некроз } \\
\hline $\begin{array}{l}\text { Ранний } \\
\text { апоптоз }\end{array}$ & $\begin{array}{c}1,6(1,6- \\
2,5)\end{array}$ & $2,1(2,0-2,3)$ & $2,9(2,8-3,0)$ & $0,6(0,6-0,7) *$ & $2,3(2,2-2,4)$ \\
\hline Апоптоз & $\begin{array}{c}2,3(1,9- \\
5,6)\end{array}$ & $7,5(7,5-7,6) *$ & $\begin{array}{c}89,8(89,7-90,0) \\
*\end{array}$ & $\begin{array}{c}95,5(95,0-96,0) \\
* \# \$\end{array}$ & $\begin{array}{c}81,0(80,0-82,0) \\
* \# \$\end{array}$ \\
\hline Некроз & $\begin{array}{c}0,8(0,4- \\
1,0)\end{array}$ & $3,5(3,4-3,6) *$ & $4,3(4,0-4,6) *$ & $\begin{array}{c}0,5(0,5-0,6) \\
* \# \$\end{array}$ & $\begin{array}{c}1,9(1,8-2,0) \\
* \# \$\end{array}$ \\
\hline
\end{tabular}

Примечание: * - достоверность различий с контролем; \# - достоверность различий с окислительным стрессом; \$ - достоверность различий с эритропоэтином; ${ }^{\wedge}$ - достоверность различий с окислительным стрессом + эритропоэтин; $\mathrm{p}<0,05$.

Дополнительно нами исследовано влияние окислительного стресса на клеточный цикл MCK (табл. 2). Окислительный стресс увеличивал долю MCK в subG0G1 (апоптоз) фазе клеточного цикла (p<0,05), но не оказывал существенного влияния на долю клеток в G0G1, G2/M и S фазах клеточного цикла.

В то же время нами показано, что наличие в питательной среде эритропоэтина для МСК, предварительно подвергшихся окислительному стрессу, увеличивало долю клеток в $\mathrm{S}$ фазе клеточного цикла по сравнению с контролем $(\mathrm{p}<0,05)$.

Кроме этого, показано, что после инкубации МСК с эритропоэтином на мембране клеток увеличена экспрессия рецептора к эритропоэтину в 2 раза (0,2/0,15-0,2 в контроле и 0,4/0,35-0,45 после инкубации с эритропоэтином; $\mathrm{p}=0,03)$, что согласуется с результатами исследования в работе авторов, также показавших, что эритропоэтин способствует экспрессии рецептора к эритропоэтину на клетках в ответ на взаимодействие с ним [6].

Таблица 2

Эффект эритропоэтина на клеточный цикл костномозговых мезенхимных стволовых клеток 
в норме и при индукции окислительного стресса

\begin{tabular}{|c|c|c|c|c|}
\hline \multirow{2}{*}{$\begin{array}{c}\text { Исследуемый } \\
\text { параметр }\end{array}$} & \multicolumn{3}{|c|}{ Функциональный потенциал мезенхимных стволовых клеток } \\
\cline { 2 - 5 } & Контроль & Эритропоэтин & $\begin{array}{c}\text { После индукции } \\
\text { окислительного } \\
\text { стресса }\end{array}$ & $\begin{array}{c}\text { После индукции } \\
\text { окислительного } \\
\text { стресса }+ \\
\text { эритропоэтин }\end{array}$ \\
\hline subG0G1 & $2,25(2,2-2,3)$ & $3,5(3,0-4,0) *$ & $4,6(4,0-5,2) *$ & $3,5(3,2-3,8) *$ \\
\hline G0G1 & $87,95(85,9-90,0)$ & $89,35(88,7-90,0)$ & $84,2(83,6-84,8)$ & $85,5(85,0-86,0)$ \\
\hline G2/M & $4,45(3,6-5,3)$ & $3,4(3,2-3,6)$ & $5,3(5,2-5,4)$ & $3,6(3,2-4,0)$ \\
\hline S & $5,2(4,2-6,2)$ & $3,9(3,8-4,0)$ & $5,9(5,8-6,0)$ & $7,4(6,8-8,0) *$ \\
\hline
\end{tabular}

Примечание: *достоверность различий с контролем; $<<0,05$.

Сохранность пролиферации, снижение апоптоза/некроза МСК, предобработанных эритропоэтином, в условиях окислительного стресса согласуются с данными других исследователей. Полученные нами из костного мозга больных ишемической болезнью сердца МСК соответствуют требованиям Комитета мезенхимных и тканевых стволовых клеток Международного сообщества по клеточной терапии (ISCT) [2], а именно прикрепляются к пластику: несут на мембране кластеры дифференцировки CD73, CD90, CD105 и не экспрессируют CD45, CD34, CD14, CD11b, CD79a, CD19 и HLA-DR; дифференцируются в остеокласты и хондроциты in vitro.

Показано, что преинкубация МСК человека с эритропоэтином защищает клетки от ишемии в модели in vitro, при этом существенная роль в выживании клеток отводится наличию на мембране клеток рецептора к эритропоэтину. Более того, было показано, что индуцированный перекисью водорода апоптоз в МСК значимо снижался после преинкубации МСК с эритропоэтином $(63,03 \pm 4,96 \%$ и 29,0 $\pm 3,41 \%$ соответственно для контроля и для преинкубированных с эритропоэтином клеток) [9].

В то же время костномозговые МСК крыс Wistar при наличии эритропоэтина в питательной среде в условиях окислительного стресса, инициированного перекисью водорода, увеличивают пролиферацию и подавляют миграцию, и не оказывают существенного влияния на уровень продукции оксида азота [10].

Известно, что эритропоэтин проявляет нейротрофическое, антиоксидантное, антиапоптотическое и противовоспалительное действие. Так, трансдукция гена эритропоэтина в МСК приводила к стойкой продукции клетками эритропоэтина [11]. Инкубация МСК с 10 МЕ/мл эритропоэтина способствовала продукции клетками эритропоэтина схожего с уровнем продукции эритропоэтина МСК с внедренным в них геном эритропоэтина. Оба типа 
клеток предохраняли от окислительного стресса, индуцированного перекисью водорода и от апоптоза, индуцированного стауроспорином, но защитный эффект более выражен у МСК с внедренным геном эритропоэтина [11].

О наличии влияния эритропоэтина на клетки не эритроидного ряда сообщается в работе [7]. Показано защитное действие эритропоэтина (300 МЕ/кг, трижды в неделю в течение 4 недель) на диабет-ассоциированные когнитивные расстройства у диабетических крыс, приводящее к улучшению пространственной ориентации и обучаемости крыс. Кроме этого, авторы показали, что эритропоэтин повышал выживаемость и активность супероксиддисмутазы, снижал продукцию малонового альдегида и активных форм кислорода, а также снижал апоптоз РC12 клеток при индукции гипергликемии и окислительного стресса [12]. Кроме этого, показано, что эритропоэтин способствует увеличению экспрессии рецептора эритропоэтина, активности фосфатидилинозитола-3, фосфорилированию Akt2 и снижению активности гликогенсинтазокиназы - $3 \beta$ [12].

Кроме этого, цитопротекторный эффект эритропоэтина опосредуется через комплекс рецептор к эритропоэтину/CD131. Показано, что антиапоптотический и противовоспалительный эффект эритропоэтина осуществляется через выпячивание на мембране клеток CD131 как ответ на клеточный стресс [13]. Авторы также показали, что воздействие через комплекс рецептор к эритропоэтину/CD131 существенно влияет на транскрипционные, трансляционные и метаболические реакции клеток после отмены стресса. Так, синтетический короткий пептид ARA290 преодолевал TNF $\alpha$ - опосредованное подавление активации фактора транскрипции, связанного со стрессовыми реакциями клеток, в первую очередь с фактором ответа сыворотки крови (SRF), белком фактора транскрипции теплового шока 1 (HSF1) и белком активатора 1 (AP1) [13].

Показано, что инкубация эндотелиальных прогениторных клеток с эритропоэтином ведет к увеличению экспрессии рецептора к эритропоэтину и CD131, которые ковалентно связаны на мембране клеток. Более того, эритропоэтин в дозе $5 \mathrm{ME} /$ мл значимо стимулировал пролиферацию, заживление дефекта монослоя клеток, миграцию и формирование сосудистоподобных структур эндотелиальными прогениторными клетками. Кроме этого, инкубация эндотелиальных прогениторных клеток с эритропоэтином повышает устойчивость клеток к индуцированному перекисью водорода апоптозу [6].

Таким образом, преинкубация клеток с эритропоэтином способствует уменьшению негативного влияния окислительного стресса на пролиферацию, апопотоз и распределение МСК в фазах клеточного цикла. Полученные данные по наличию антиоксидантного влияния эритропоэтина на МСК могут быть использованы в регенеративной медицине с целью повышения терапевтического потенциала стволовых клеток при имплантации их в 
неблагоприятное микроокружение в поврежденных органах и тканях.

\section{Выводы}

1. Преинкубация мезенхимных стволовых клеток с эритропоэтином отменяет негативный эффект окислительного стресса на пролиферативный потенциал клеток, а также снижает апоптоз/некроз таких клеток.

2. Протекторное действие эритропоэтина на пролиферацию мезенхимных стволовых клеток, подвергшихся окислительному стрессу, не выявлено, но при этом снижается доля клеток в раннем апоптозе и доля мертвых клеток.

3. Эритропоэтин существенно не оказывал влияния на нахождение мезенхимных клеток, подвергшихся окислительному стрессу, в фазах клеточного цикла.

4. Преинкубация мезенхимных клеток с эритропоэтином усиливает экспрессию рецептора к эритропоэтину на клеточной мембране.

\section{Список литературы}

1. Кочегура Т.Н., Ефименко А.Ю., Акопян Ж.А., Парфенова Е.Е. Клеточная терапия сердечной недостаточности: клинический опыт, проблемы и перспективы // Клеточная трансплантология и тканевая инженерия. 2010. № 2. С. 11-18.

2. Wuchter P., Bieback K., Schrezenmeier H., Bornhauser M., Muller L.P., Bonig H., Wagner W., Meisel R., Pavel P., Tonn T., Lang P., Muller I., Renner M., Malcherek G., Saffrich R., Buss E.C., Horn P., Rojewski M., Schmitt A., Ho A.D., Sanzenbacher R., Schmitt M. (2015). Standardization of Good Manufacturing Practice-compliant production of bone marrow-derived human mesenchymal stromal cells for immunotherapeutic applications. Cytotherapy. no.17(2). P.128-139.

3. Muhammad S.A., Nordinm N., Fakurazi S. 2018. Regenerative potential of secretome from dental stem cells: a systematic review of preclinical studies. Rev. Neurosci. no.29(3). P.321-332.

4. Ефименко А.Ю., Старостина Е.Е., Рубина К.А., Калинина Н.И., Парфенова Е.В. Влияние гипоксии и воспалительных факторов на жизнеспособность и ангиогенную активность мезенхимальных стромальных клеток из жировой ткани и костного мозга. // Цитология. 2010. №2. С.144-154.

5. Лыков А.П., Бондаренко Н.А., Сахно Л.В., Шевела Е.Я., Повещенко О.В., Ким И.И., Никонорова Ю.В., Коненков В.И. Влияние секреторных факторов эндотелиальных клеток на пролиферативную и миграционную способность мультипотентных мезенхимальных стромальных клеток человека. // Фундаментальные исследования. 2014. № 4(2). С. 296-301.

6. Bennis Y., Sarlon-Bartoli G., Guillet B., Lucas L. Pellegrini L., Velly L., Blot-Chabaud M., 
Dignat-Georges F., Sabatier F., Pisano P. Priming of late endothelial progenitor cells with erythropoietin before transplantation requires the CD131 receptor subunit and enhances their angiogenic potential. J. Thromb. Haemost. 2012. V. 10(9). P. 1914-1928. DOI: 10.1111/j.15387836.2012.04835.x.

7. Захаров М.Ю. Цитопротекторные функции эритропоэтина // Клиническая нефрология. 2009. № 1. C. 16-21.

8. Zhang S., Shi B. Erythropoietin modification enhances the protection of mesenchymal stem cells on diabetic rat-derived Schwann cells implications for diabetic neuropathy. BioMed. Res. Int. 2017. Vol.2017. 352858. DOI: 10.1155/2017/6352858.

9. Ercan E., Bagla A.G., Aksoy A., Gacar G., Unal Z.S., Asgun H.F., Karaoz E. In vitro protection of adipose tissue-derived mesenchymal stem cells by erythropoietin. Acta Histochem. 2014. Vol. 116(1). P. 117-125. DOI: 10.1016/j.acthis.2013.06.007.

10. Lykov A.P., Nikonorova Y.V., Bondarenko N.A., Poveshchenko O.V., Kim I.I., Poveshchenko A.F., Konenkov V.I. Proliferation, migration, and production of nitric oxide by bone marrow multipotent mesenchymal stromal cells from Wistar rats in hypoxia and hyperglycemia. Bull. Exp. Biol. Med. 2015. Vol. 159(4). P. 443-445. DOI: 10.1007/s10517-015-2986-6.

11. Kim M.H., Cho G.W., Huh Y.M., Kim S.H. Transduction of human EPO into human bone marrow mesenchymal stromal cells synergistically enhanced cell-protective and migratory effects. Mol. Biol. (Mosk). 2010. Vol. 44(4). P. 656-663.

12. Wang M., Yan W., Liu Y., Hu H., Sun Q., Chen X., Zang W., Chen L. Erythropoietin ameliorates diabetes-associated cognitive dysfunction in vitro and in vivo. Sci. Rep. 2017. Vol. 7(1). P. 2801. DOI:10.1038/s41598-017-03137-6.

13. Bohr S., Patel S.J., Vasko R., Shen K., Iracheta-Vellve A., Lee J., Bale S.S., Chakraborty N., Brines M., Cerami A., Berthiaume F., Yarmush M.L. Modulation of cellular stress response via the erythropoietin/CD131 heteroreceptor complex in mouse mesenchymal-derived cells. J. Mol Med. (Berl). 2015. Vol. 93(2). P. 199-210. DOI: 10.1007/s00109-014-1218-2. 